Sains Malaysiana 49(5)(2020): 1129-1136

http://dx.doi.org/10.17576/jsm-2020-4905-18

\title{
Photothermal Imaging using Non-Contact Photopyroelectric Method
}

(Pengimejan Fototerma menggunakan Kaedah Fotopiroelektrik Tidak Bersentuhan)

\author{
AzUra Amran, Nor Kamilah SAAT*, NizAm TAMCHEK \& Ting LEE MON
}

\begin{abstract}
Photothermal imaging is a non-destructive and contactless technique for testing and monitoring defect of materials. This work is demonstrated thermal images for film sample of $\mathrm{Al}, \mathrm{Cu}, \mathrm{Ni}$, and $\mathrm{Cu}$ with artificial defect with sampling area of $10 \mathrm{~mm} \times 12 \mathrm{~mm}(21 \times 25$ pixels $), 10 \mathrm{~mm} \times 14 \mathrm{~mm}(21 \times 29$ pixels $), 10 \mathrm{~mm} \times 14 \mathrm{~mm}(21 \times 29$ pixels $), 10 \mathrm{~mm} \times 10$ $\mathrm{mm}(21 \times 21$ pixels $)$ respectively, acquired by raster scanning with the step size of $500 \mu \mathrm{m}$ at fixed frequency modulation of $6 \mathrm{~Hz}$ and lock in detection in the range of 50 to $500 \mathrm{mV}$ depending of studied material. The thermal image of defect sample is successfully acquired by introducing artificial defect onto the sample of Cu film. The thermal signal is obtained by taking transmission measurement which is defined by the ratio of intensity with sample to without sample. This paper also involves a photopyroelectric non-contact configuration for thermal diffusivity of the Al, $\mathrm{Cu}$, and Ni film samples. Normalization procedure was used to wipe out the amount of photopyroelectric cell media parameter that should usually known before the sample's thermal diffusivity could be decided. In this case, sample Al, Cu, and Ni were nearly to literature values but therefore justified the suggested model, the thermal diffusivity acquired.
\end{abstract}

Keywords: Photopyroelectric; photothermal; thermal diffusivity

ABSTRAK

Pengimejan fototerma adalah teknik yang tidak merosakkan dan tidak bersentuhan untuk menguji dan memantau kecacatan bahan. Projek ini menunjukkan imej terma untuk sampel filem Al, Cu, Ni dan Cu dengan kecacatan tiruan dengan luas sampingan $10 \mathrm{~mm} \times 12 \mathrm{~mm}(21 \times 25$ piksel $), 10 \mathrm{~mm} \times 14 \mathrm{~mm}(21 \times 29$ piksel $), 10 \mathrm{~mm} \times 14 \mathrm{~mm}(21 \times 29$ piksel), $10 \mathrm{~mm} \times 10 \mathrm{~mm}(21 \times 21$ piksel), yang diperoleh dengan pengimbasan raster dengan saiz langkah $500 \mu \mathrm{m}$ pada modulasi frekuensi tetap $6 \mathrm{~Hz}$ dan pengesanan mengunci dalam julat 50 hingga $500 \mathrm{mV}$ bergantung kepada bahan yang dikaji. Imej terma untuk sampel kecacatan berjaya diperoleh dengan memperkenalkan kecacatan tiruan untuk sampel filem $\mathrm{Cu}$. Isyarat terma yang diperoleh dengan mengambil pengukuran penghantaran yang ditentukan oleh nisbah keamatan dengan sampel kepada tanpa sampel. Kertas ini juga melibatkan konfigurasi tidak bersentuhan fotopiroelektrik untuk peresapan haba dalam sampel Al, Cu dan Ni. Prosedur normalisasi digunakan untuk memadam jumlah parameter media sel fotopiroelektrik yang perlu diketahui sebelum peresapan haba sampel dapat diketahui. Dalam kes ini, peresapan haba untuk sampel Al, Cu dan Ni hampir sama dengan nilai kesusasteraan menggunakan model yang dicadangkan.

Kata kunci: Fotopiroelektrik; fototerma; peresapan haba

\section{INTRODUCTION}

In the field of thermal parameters for material, the photothermal (PT) technique has been used extensively since 1985. The fundamental idea behind these aspect is applying an amplitude modified heating beam at a frequency concentrated onto the sample surface for the purpose of produce a temperature change at frequency that can detected by varying ways such as laser flash method (Parker 1979; Taylor 1961) and mirage technique (Murphy 1980; Wong et al. 1998). The sample can be scanned in a raster manner, while the detected signal is used to brightness modify a scan and display at the same time as to construct an image. There have recently been numerous relevant photopyroelectric (PPE) applications in the measurement of the thermal as well as optical absorption properties of solids. A thin film pyroelectric detector produces a voltage proportional to its variations in surface temperatures, as thermal waves propagate with the thin pyroelectric PVDF in close contact with the sample.

THEORY

PPE effect is a reaction caused by the PE sensor's periodic optical rotation or by periodic heating of the material in the thermal contact to the PE sensor that regulates the detection of PE. The light intensity on the sample surface is determined (Sang et al. 2003).

$$
(\omega)=\frac{1}{2} I_{\circ}(1+\cos \omega t)
$$


$I_{o}$ and $\omega$ provided the amplitude of light incidence and the modulation angular frequency on the sample surface. The light is absorbed in the sample then converts into heat that diffused to the transducer through the sample. The heat generates a piezoelectric polymer, which acts as a PE transducer, with a voltage (Mandelis 2011).

The sample is mounted in thermal contact between the PE sensor and the TW generator. For generating the TW generator, a modulated laser beam is used. The TW generator absorbs the laser light and converts it into TW that is diffused via the sample to the PE detector. The TW is reflected and transmitted by the transmission coefficient $\mathrm{T}_{12}$ and reflection coefficient $\mathrm{R}_{12}$ for $\mathrm{TW}$ propagating from medium 1 through medium 2 , as it cross the limits of two different materials as follows (Almond 1996; Bennett 1982).

$$
R_{12}=\frac{1-b_{12}}{1+b_{12}}, \quad T_{12}=\frac{2}{1+b_{12}}
$$

The variable $b_{12}$ shows the ratio of the thermal effusivity of material 1 to material 2 . The complete duration of the sample transmission of the TW will provide the PE back detection signal PE. If the sample is extremely opaque as well as the optical absorption length is lower than the sample thickness, this technique is further facilitated by taking into account only the sample surface produced by heat source. The thermal wave results in an autonomous sample of the optical characteristics.

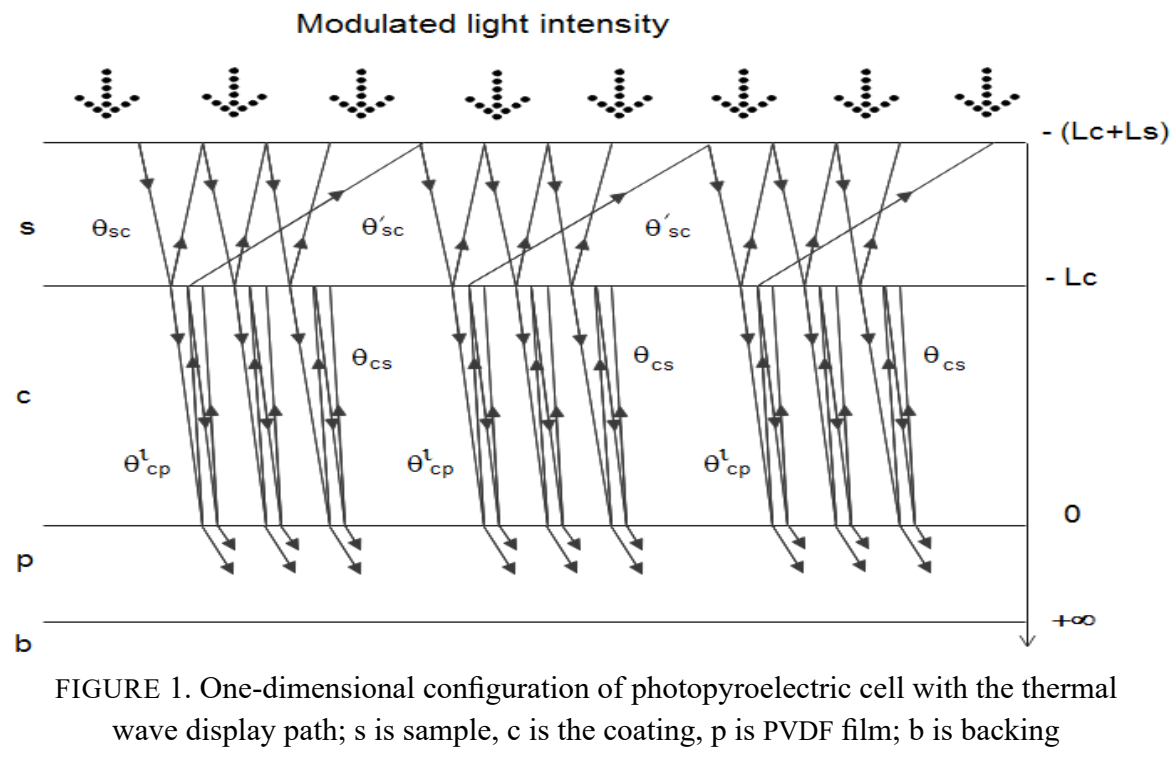

Figure 1 shows the one dimensional configurations of the PPE cell and thermally thin condition layer of the coating-gap in a and the transducer of PE and backing in thermally thick condition, the wave transmitted and the reflected wave the sample coating boundary, respectively, are (Bennett 1982).

$$
\theta_{s c 1}=T_{s c} A e^{-\sigma_{s} L_{s}}, \quad R_{s c 1} A e^{-\sigma_{s} L_{s}}
$$

where $T_{s c}$ is transmitted wave on the boundary sample coating; $R_{s c l}$ is the reflected wave at sample-coating boundary; $A=Q_{\sigma} / 2 K_{s} \sigma_{s} ; Q_{0}$ is the intensity of the source; $K_{j}$ is thermal conductivity; $\sigma j=(1+i) / \mu j ; \quad \mu_{j} \sqrt{\alpha_{j} / \pi f}$ is thermal diffusion length of the light modulation frequency $f ; L s$ is the thickness; $\alpha j=K_{j} / \rho_{j} C_{j}$ is thermal diffusivity, whereas the $\rho_{j}$ is the density; and $C j$ is the specific heat of medium; and $j(=s, c p, b)$ where $\mathrm{s}$ is the sample; $c$ is the coating; $p$ is PVDF film and $b$ is backing.
In a thermally thin sample, the reflected waves will then be reflected between the sample-coating interfaces $\mathrm{X}=$ $-L_{c}$ and $\mathrm{X}=\left(-L_{c}+L_{s}\right)$, and the coating gap transmission at $\mathrm{X}=-L_{c}$. The first wave was transmitted $\theta_{s c 1}$ is then given as (Zakaria et al. 2006)

$$
\theta_{s c}=\frac{T_{s c} A e^{-\sigma_{s} L_{s}}}{1-R_{s c}{ }^{2} e^{-2 \sigma_{s} L_{s}}}
$$

In the coating gap, a further series reflection will be performed by the transmitted thermal wave in $X=-L_{C}$ where the sample coating gaps and the coating PVDF interfaced of $X=0$ and the transmissions at interfaces will occur. The first sequence of transmitted waves is given by the following $\theta_{s c} \theta_{c p}{ }^{l}=\theta_{s c} T_{c p} e^{-\sigma c L c} /\left(1-R_{c s} R_{c p} e^{-2}\right.$ $\left.{ }^{\sigma c L c}\right)$ which responsible for the PVDF sensor surface temperature. The second transmitted series to the $X=0$ is given with $\theta_{s c} \theta_{c s} \theta_{s c}^{\prime} \theta_{c p}^{\prime}$ which comes from the reflected 
wave, $\theta_{s c} \theta_{c s}=\theta_{s c} T_{c s} R_{c p} e^{-2 \sigma c L c} /\left(1-R_{c p} R_{c s} e^{-2 \sigma c L c}\right)$ at $X=-L_{C}$, that experience multiple reflection in the sample, and the transmitted into the sample at $X=-L_{C}$ that is $\theta_{s c} \theta_{c s}$ $\theta_{s c}^{\prime}=\theta_{s c} \theta_{c s} R_{s c} T_{s c} e^{-2 \sigma c L c} /\left(1-R^{2} e^{-2 \sigma c L c}\right)$, which subsequently undergoes various interface reflection and transmission. At $X=-L_{C}$ the above process is repeated to the third series $\theta_{s c} \theta_{c s} \theta_{s c}^{\prime} \theta_{c s} \theta_{s c}^{\prime} \theta_{c p}^{\prime}$ by transmitting the waves and infinitely follow the following sequence of terms forwarded to the PVDF film. The infinite geometric series with ratio $\theta_{c s} \theta_{s c}$ may be depicted. The surface temperature of the PVDF can therefore be recorded (Bennett 1982; Zakaria et al. 2006).

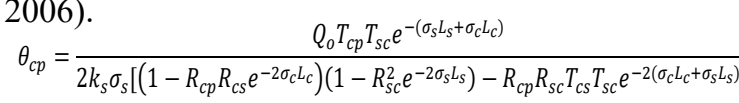

The film has an average temperature of $\theta_{p}$

$$
\theta_{p}(\omega)=\frac{\theta_{c p}}{L_{p}} \int_{0}^{L_{p}} e^{-\sigma_{p} x} d x
$$

The average PE voltage $V(\omega)$ generated by the PVDF film is $p \mathrm{~L}_{p} \theta_{p} / \varepsilon \varepsilon_{0}$ hence by using expression $\theta_{p}$ in eq. (5), the voltage may be indicated as (Zakaria et al. 2006)

$$
=\frac{V(\omega)}{2 \varepsilon \varepsilon_{0} k_{s} \sigma_{s} \sigma_{p}\left[\left(1-R_{c p} R_{c s} e^{-2 \sigma_{c} L_{c}}\right)\left(1-R_{s c}^{2} e^{-2 \sigma_{s} L_{s}}\right)-R_{c p} R_{s c} T_{c s} T_{s c} e^{-2\left(\sigma_{c} L_{c}+\sigma_{s} L_{s}\right)}\right]}
$$

where $\mathrm{p}$ is the PE coefficient; $\varepsilon$ is the dielectric constant of the PE detector; and the $\varepsilon_{\mathrm{o}}$ is the vacuum permittivity constant. For a particular situation, such as for the sample's thermally thick condition, we have $e^{-2 \sigma c L c} \approx 0$ or $\left(1-R_{s c}^{2} e^{-2} \sigma c L c\right) \approx 1$. Furthermore, the normalizing of the test signal for the reference sample could remove a number of pertinent values for the coating and PVDF film. The term denominator $\left(1-R_{c p} R_{c s} e^{-2 \sigma c L c}\right)$, can also be cancelled in this method because the values of the coating-to-sample reflection coefficient, $\mathrm{R}_{\mathrm{cs}}$, of most metals are usually very tightly linked to each other(Azmi 2004). Therefore, (7) can be interpreted into

$$
\begin{gathered}
\frac{V_{s}}{V_{r}}(\omega)=C \frac{e^{-\sigma_{s} L_{s}}}{e^{-\sigma_{r} L_{r}}} \\
\frac{V_{s}}{V_{r}}(\omega)=C \exp \left[-\sqrt{\frac{\pi f}{\alpha_{s}}} L_{s}+\sqrt{\frac{\pi f}{\alpha_{r}}} L_{r}\right] x \exp \left\{\left[-\sqrt{\frac{\pi f}{\alpha_{s}}} L_{s}+\sqrt{\frac{\pi f}{\alpha_{r}}} L_{r}\right]\right\} \\
\left(\frac{k_{r} \sigma_{r} T_{s c}}{k_{s} \sigma_{s} T_{r c}}\right)
\end{gathered}
$$

where $\mathrm{C}={ }^{k_{s} \sigma_{s} T_{r c}}$ and sample and reference sample are respectively, represented by subscripts $\mathrm{s}$ and $\mathrm{r}$. According to the Delenclos et al. (2001) the equation (9) is comparable but with distinct constant, $\mathrm{C}$. In order to achieve thermal diffusivity, the constant $\mathrm{C}$ is trivial and not regarded as it is sample reflectivity which is sample dependent. Through using the natural logarithm to (9) to achieve its magnitude, the sample thermal diffusivity can be measured using

$$
\alpha_{s}=\left[\frac{\sqrt{\pi} L_{s}}{\sqrt{\pi L_{r}{ }^{2} / \alpha_{r}}-m}\right]^{2}
$$

where $\mathrm{m}$ is the gradient of an amplitude plot normalized In $V / V_{r}$ agains $/$ frequency square root or normalized plot of $\mathrm{O}_{s}-\mathrm{O}_{r}$ against square root of frequency. By substitute $m, L_{s}, L_{r}$ and $\alpha_{r}$ into (10), the sample's thermal diffusivity $\alpha_{s}$ can be established (Zakaria et al. 2006).

\section{MATERIALS AND METHODS}

\section{PHOTOTHERMAL IMAGING}

The scheme of the PPE experimental configuration is shown in Figure 2. The frequency chopper (Stanford Research, SR540) modulates the beam intensity of $150 \mathrm{~mW}$ He-Ne laser $(532 \mathrm{~nm})$ to give pulse laser and reflected using a mirror and focused onto the PVDF thin film supported $1.2 \mathrm{~cm}$ thick Perspex backing where the sample is placed on top of the PVDF film. The output from the pyroelectric detector is supplied into a lock-in amplifier (Stanford Research, SR530) to lock the output signal with sensitivity range of 50 to $500 \mathrm{mV}$ depending of studied material and time constant of $3 \mathrm{~s}$. To produce photothermal image, the laser beam is modulated by frequency chopper at fixed frequency modulation of 6 $\mathrm{Hz}$. The sample was raster scanned is $\mathrm{x}$ and $\mathrm{y}$ direction using computer controlled translation stage with a step size of $500 \mu \mathrm{m}$ producing $21 \times 25$ pixels for $\mathrm{Al}$ film sample; $21 \times 29$ pixels for $\mathrm{Cu}$ and Ni film samples; 21 $\times 21$ pixels for $\mathrm{Cu}$ with artificial defect film sample corresponding to an image area $10 \mathrm{~mm} \times 12 \mathrm{~mm}, 10$ $\mathrm{mm} \times 14 \mathrm{~mm}$ and $10 \mathrm{~mm} \times 10 \mathrm{~mm}$, respectively. The thickness of the studied sample of $\mathrm{Al}, \mathrm{Cu}, \mathrm{Ni}$, and $\mathrm{Cu}$ with artificial defect is $500 \mu \mathrm{m}, 800 \mu \mathrm{m}, 500 \mu \mathrm{m}$ and $5000 \mu \mathrm{m}$, respectively. The $\mathrm{Cu}$ with artificial defect is done by small hole and covered with carbon tape.

\section{THERMAL DIFFUSIVITY}

For thermal diffusivity measurement using the same setup, the laser beam is modulated at variable frequency modulation from $5 \mathrm{~Hz}$ up to $11 \mathrm{~Hz}$. To optimize the sample sensor for thermal contact, a very thin thermal grease layer has been used. The grease layer affects the measured signal; in addition the normalization process can eliminate it. The PE signal output is supplied for signal analysis with a lock-in amplifier (SR530). Measurement of $\mathrm{Al}\left(\mathrm{L}_{\mathrm{s}}=500 \mu \mathrm{m}\right), \mathrm{Cu}(\mathrm{Ls}=800 \mu \mathrm{m})$ and $\mathrm{Ni}(\mathrm{Ls}=500 \mu \mathrm{m})$ was done at room temperature and PPE signal was detected in a static position over a frequency 


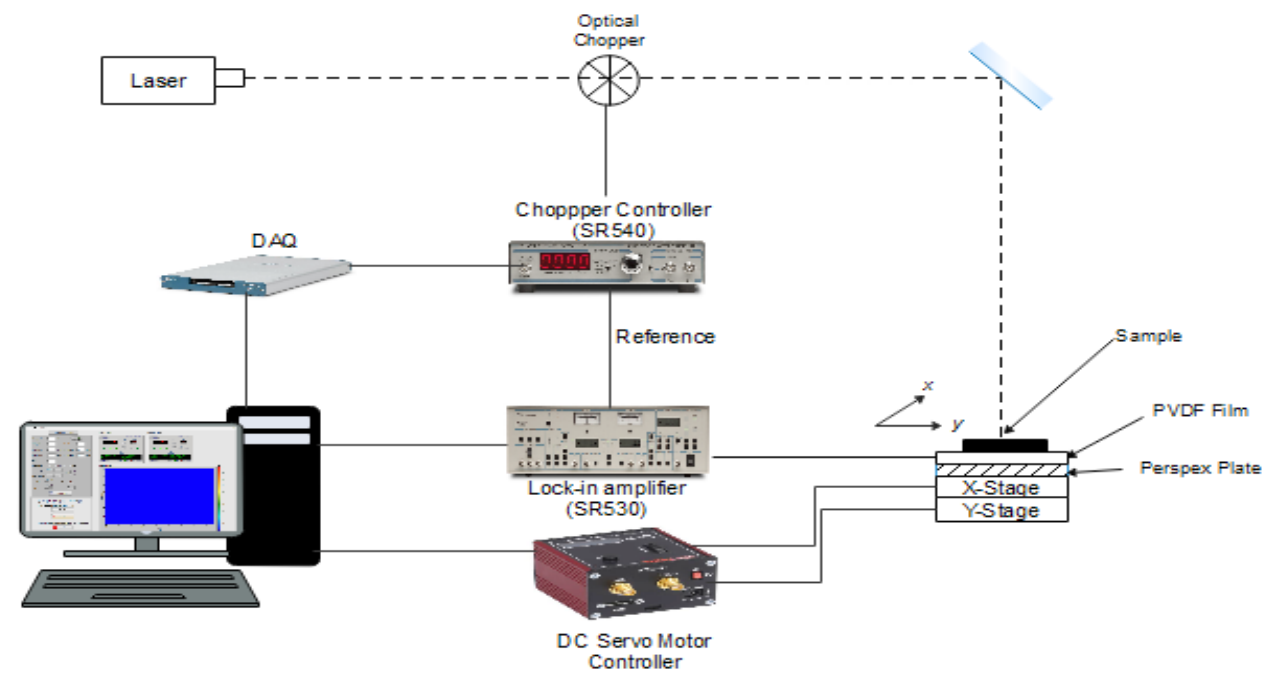

FIGURE 2. The scheme of the PPE experimental configuration

range in keeping with the theory approach. RESULTS AND DISCUSSION

\section{PHOTOTHERMAL IMAGING}

Figure 3(a), 3(b), 3(c) and 3(d) shows the amplitude image acquired by raster scanning at $6 \mathrm{~Hz}$ for different types of tested samples of $\mathrm{Al}, \mathrm{Cu}, \mathrm{Ni}$, and $\mathrm{Cu}$ with artificial defect, respectively. The amplitude images were acquired directly from photothermal imaging system by measuring the voltage signal by PVDF which depends on the magnitude of the thermal waves, and then detected by lock-in amplifier. All images are displayed in red to blue color ranges so that red corresponds to a high signal and blue to low signal. The higher signal show that the signal detected on the PVDF film itself. Meanwhile, the lower signals onto the sample might be due to the thickness of sample. Green color range shows the signal between PVDF film and edge of samples. Figure 3(a) shows that the photothermal image of aluminum with sampling area of $10 \mathrm{~mm} \times 12 \mathrm{~mm}$ corresponding to 525 pixels. Figure 3(b) shows that the photothermal image of copper with sampling area of $10 \mathrm{~mm} \times 14 \mathrm{~mm}$ corresponding to 609 pixels. Figure 3(c) shows that the photothermal image of nickel with sampling area of 10 $\mathrm{mm} \times 14 \mathrm{~mm}$ corresponding to the 609 pixels. The low signal was measured by PVDF film and then detected using lock-in amplifier showed in blue color ranges. Figure 3(d)(i) shows the photothermal image of copper with artificial defect with sampling area of $10 \mathrm{~mm} \times 10$ $\mathrm{mm}$ corresponding to 441 pixels. Meanwhile, Figure 3(d) (ii) shows zoom in of the photothermal image of copper with artificial defect. The signal was detected in artificial defect region was quite weak. It does not give clearly image of defect itself. All the images of photothermal of sample film depend on the thickness and source of laser (a)

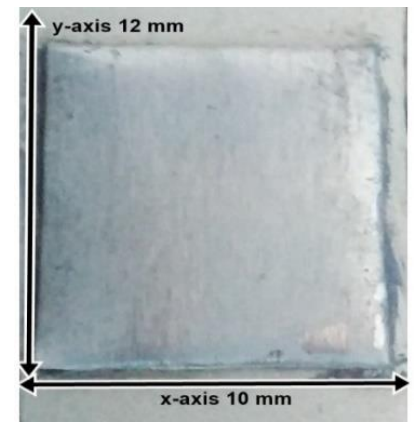

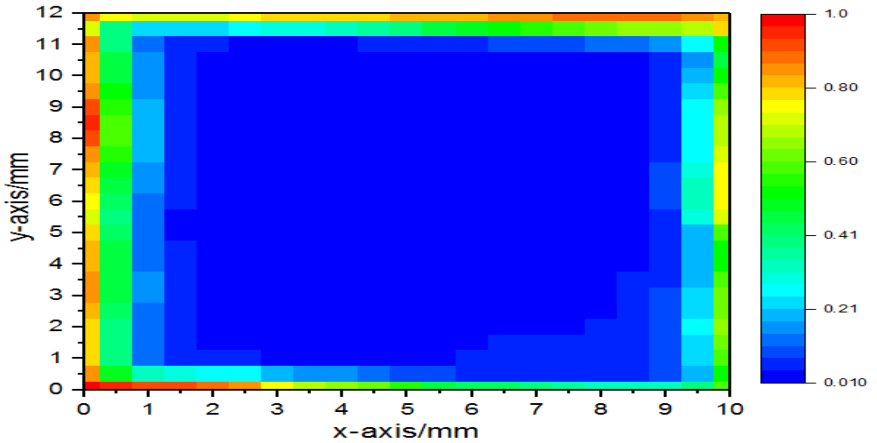


(b)

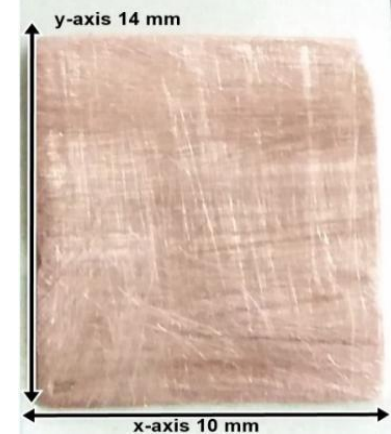

(c)

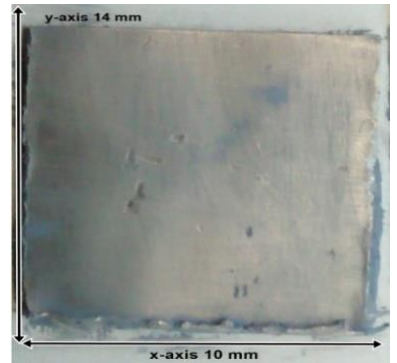

(d)

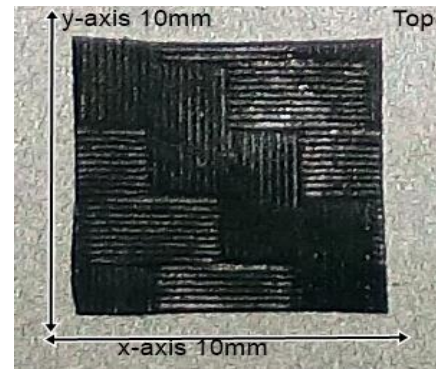

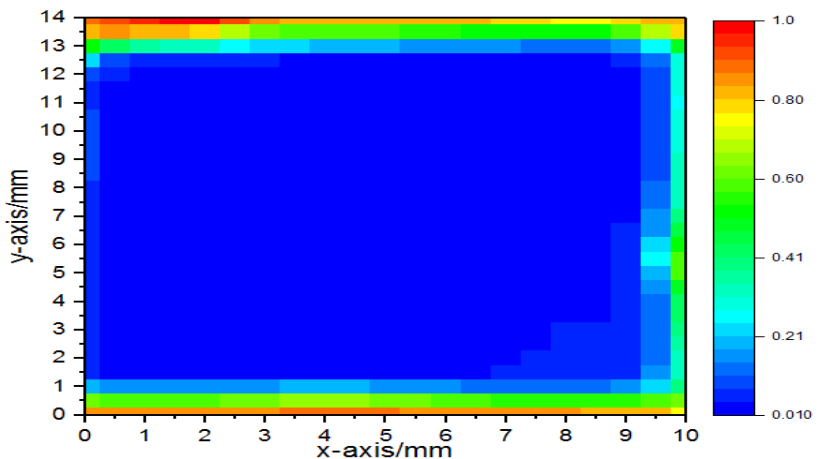
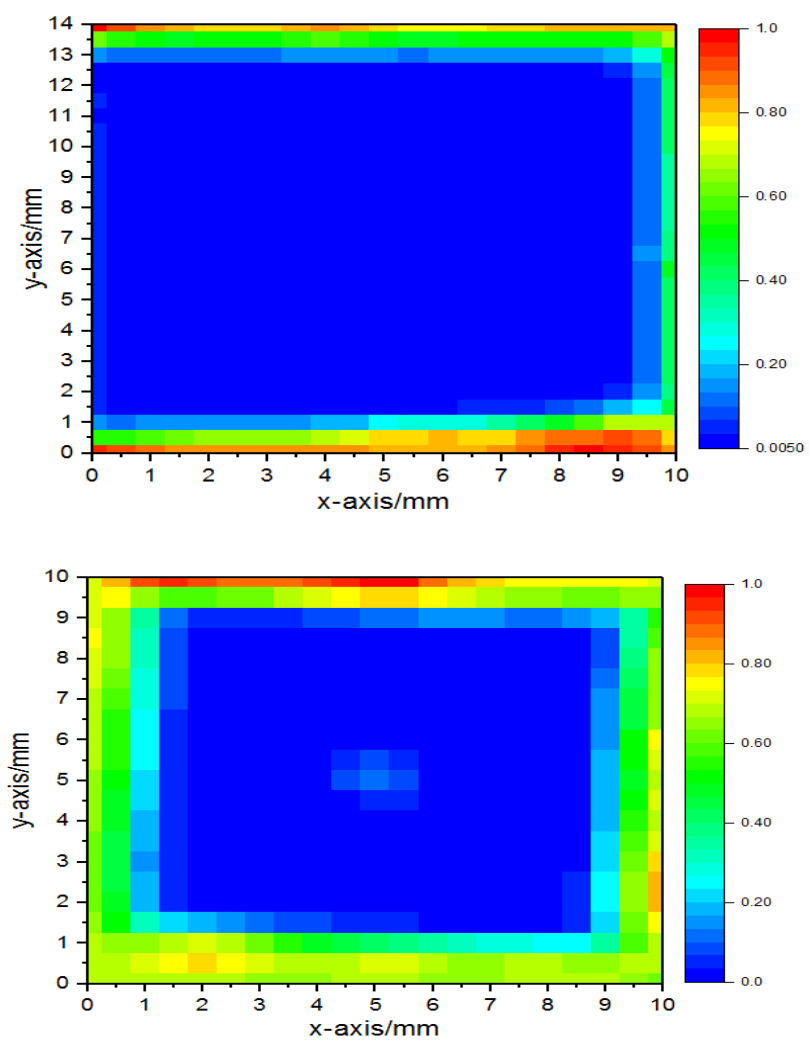

(i)

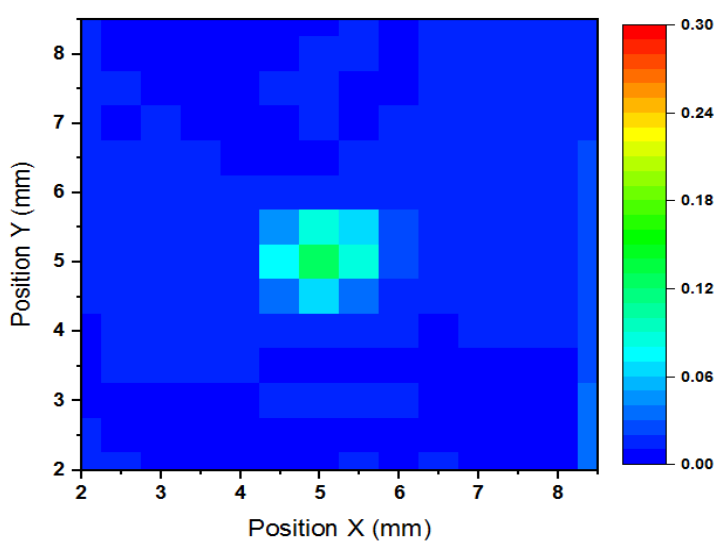

(ii)

FIGURE 3. The amplitude image acquired by raster scanning at $6 \mathrm{~Hz}$ for different types of tested samples: (a) $\mathrm{Al}$, (b) $\mathrm{Cu}$, (c) $\mathrm{Ni}$, and (d) $\mathrm{Cu}$ (i) with artificial defect, and (ii) zoom in the area of defect 
itself.

\section{THERMAL DIFFUSIVITY}

The exponential decay of PPE amplitude signal in $f$ for all the samples studied is shown in Figure 4. In this work, the level of amplitude corresponding to the limit of the detected signal is between $0.014 \mathrm{~V}$ and $0.002 \mathrm{~V}$ at frequency range of 5 to $11 \mathrm{~Hz}$ for the entire $\sqrt{f}$

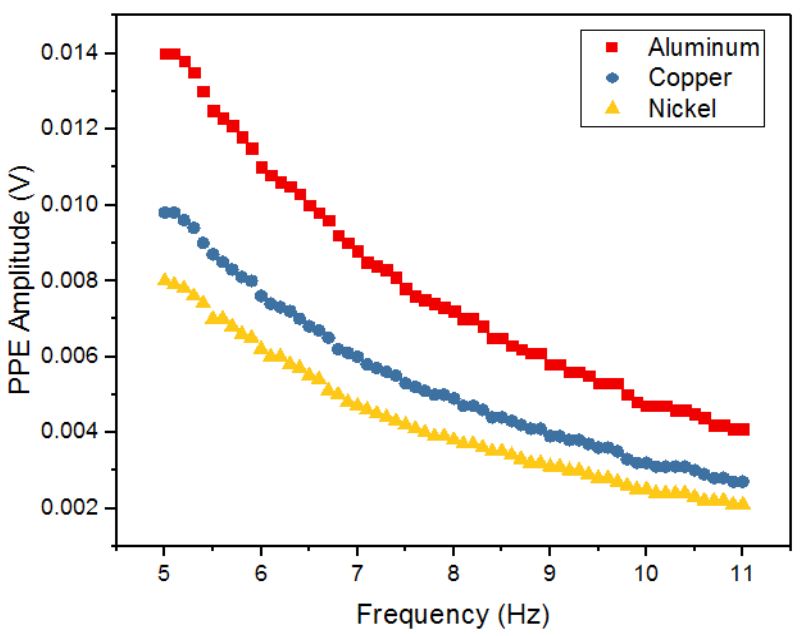

FIGURE 4. The experimental photopyroelectric amplitude signal against frequency

and the samples in thermally thin condition will be decreased shortly after this initial frequency.

Figure 6 and 7 illustrated $\mathrm{Al}$ and $\mathrm{Ni}$ as reference plot with normalized phase signal and $\ln \mathrm{V}$ signal. For the gradient and calculation of the value of the thermal diffusivity value of the studied sample, the linear fitting equation was used in both plots (Figures 6 \& 7). For studied samples. Figure 5 demonstrates the linear PPE phase signal respect to for all studie 1 satroplesf over modulation frequency range of $5-11 \mathrm{~Hz}$. For $\mathrm{Al}, \mathrm{Cu}$, and $\mathrm{Ni}$, the thermal diffusion length, at 5 $\mathrm{Hz}$ where $\alpha$ is the average value of thermal diffusivity of sample in Table 1 is around about $2527 \mu \mathrm{m}, 2774 \mu \mathrm{m}$ and $1187 \mu \mathrm{m}$, respectively; the frequency will be increased

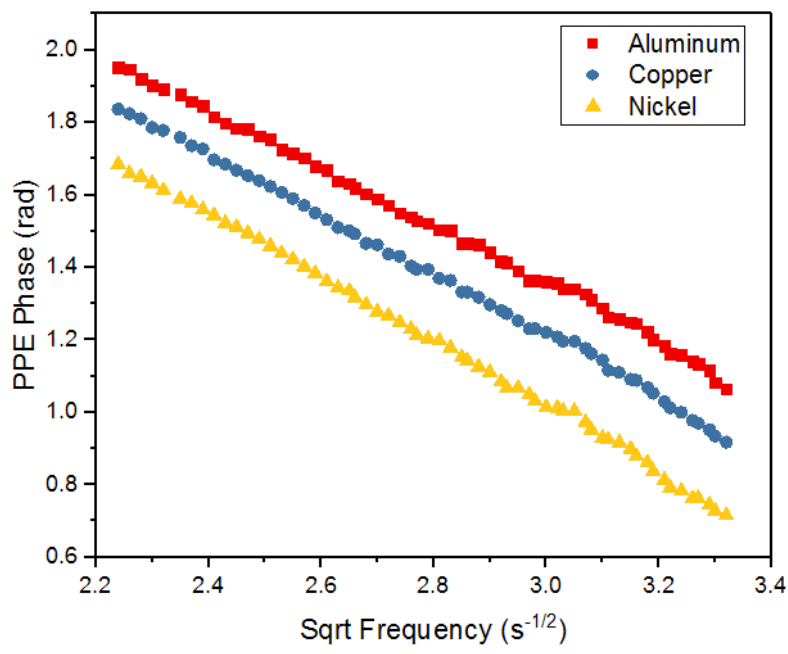

FIGURE 5. The experimental photopyroelectric phase signals against square root of frequency

example, the thermal diffusivity of $\mathrm{Al}$ calculated by replacing the thermal diffusivity of $\mathrm{Ni}$ literature value is $1.0486 \times 10^{-4} \mathrm{~m}^{2} \mathrm{~s}^{-1}$ when using $\mathrm{m}$ from the normalized phase (Figure 6). Meanwhile, thermal diffusivity of $\mathrm{Al}$ is $0.9425 \times 10^{-4} \mathrm{~m}^{2} \mathrm{~s}^{-1}$ when using $\mathrm{m}$ from the normalized amplitude (Figure 7). The experimental error only

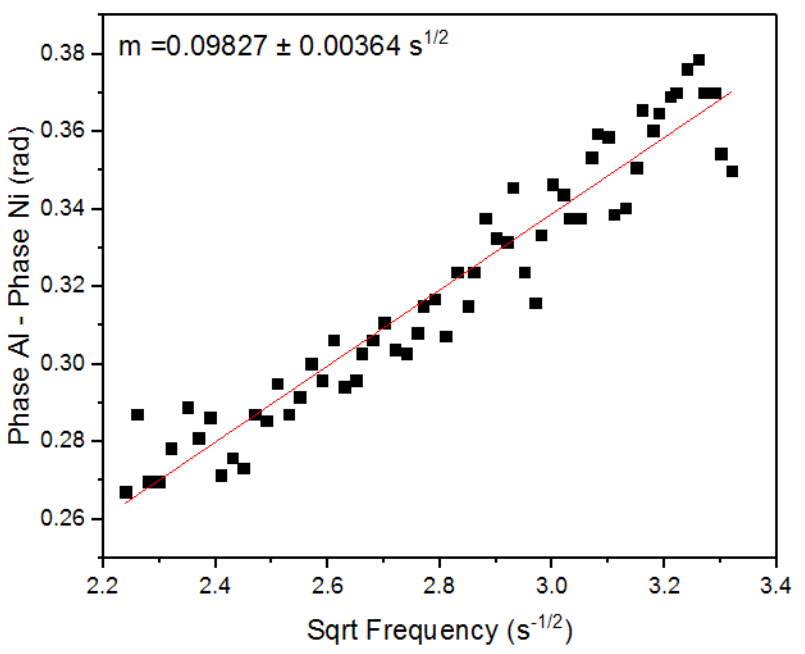

FIGURE 6. The normalized aluminum phase signal with the nickel as reference material

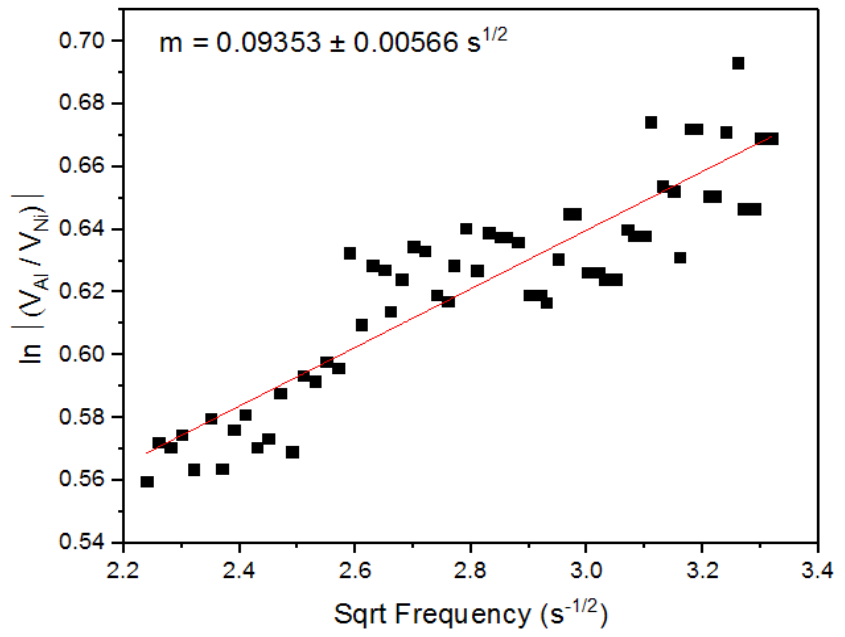

FIGURE 7. The normalized aluminum amplitude signal with nickel as reference material 
outcomes from error in the measurement of sample thickness and error from PPE cell components.

By using (10) in Table 1, the calculated values of $\alpha$ were shown in the context of the various reference sample and the outcome obtained is sensible to the literature values, which is not as high as $4 \%$. Only error in the measuring sample thickness and gradient of the plot are responsible for the experimental mistake. Table 2 , the amplitude signal provides nice of $2 \%$ thermal diffusivity to literature values (Lide 1997) for samples that have been normalized in different reference samples. By using the normalization technique, the reflected term in the sample of the air interface is simply overlook, as in the sample which is removed at the interface after a reflection at the interface, the modulated frequency is generated, for very short wavelength and brief thermal diffusion length. Likewise, due to its brief thermal

diffusion length relative to its thickness physical no reflection in the PVDF film is taken into consideration.

TABLE 1 . Thermal diffusivity achieved by phase signal and literature value comparison

\begin{tabular}{ccccccc}
\hline Sample & \multicolumn{2}{c}{$\begin{array}{c}\text { Measured value }\left(\times 10^{-4} \mathrm{~m}^{2} \mathrm{~s}^{-1}\right) \\
\mathrm{Al}\end{array}$} & $\begin{array}{c}\mathrm{Cu} \\
\text { (as reference) }\end{array}$ & $\begin{array}{c}\text { Average } \\
(\text { as reference }\end{array}$ & $\begin{array}{c}\text { Literature value } \\
\left(\times 10^{-4} \mathrm{~m}^{2} \mathrm{~s}^{-1}\right)\end{array}$ & $\begin{array}{c}\text { Literature } \\
\text { deviation }(\%)\end{array}$ \\
\hline $\mathrm{Al}$ & - & $0.9578 \pm 0.0027$ & $1.0486 \pm 0.1085$ & 1.0032 & 0.9790 & 2.47 \\
$\mathrm{Cu}$ & $1.1804 \pm 0.0019$ & - & $1.2374 \pm 0.127$ & 1.2089 & 1.1630 & 3.95 \\
$\mathrm{Ni}$ & $0.2225 \pm 0.0005$ & $0.2202 \pm 0.0006$ & - & 0.2213 & 0.2300 & 3.78 \\
\hline
\end{tabular}

TABLE 2 . Thermal diffusivity achieved by amplitude signal and literature value comparisons

\begin{tabular}{|c|c|c|c|c|c|c|}
\hline \multirow[t]{2}{*}{ Sample } & \multicolumn{3}{|c|}{ Measured value $\left(\times 10^{-4} \mathrm{~m}^{2} \mathrm{~s}^{-1}\right)$} & \multirow{2}{*}{$\begin{array}{c}\text { Average } \\
\left(\times 10^{-4} \mathrm{~m}^{2} \mathrm{~s}^{-1}\right)\end{array}$} & \multirow{2}{*}{$\begin{array}{l}\text { Literature value } \\
\qquad\left(\times 10^{-4} \mathrm{~m}^{2} \mathrm{~s}^{-1}\right)\end{array}$} & \multirow{2}{*}{$\begin{array}{c}\text { Literature } \\
\text { deviation } \\
(\%)\end{array}$} \\
\hline & $\begin{array}{c}\mathrm{Al} \\
\text { (as reference) }\end{array}$ & $\begin{array}{c}\mathrm{Cu} \\
\text { (as reference) }\end{array}$ & $\begin{array}{c}\mathrm{Ni} \\
\text { (as reference }\end{array}$ & & & \\
\hline $\mathrm{Al}$ & - & $0.9830 \pm 0.0028$ & $0.9426 \pm 0.0975$ & 0.9628 & 0.9790 & 1.65 \\
\hline $\mathrm{Cu}$ & $1.1596 \pm 0.0019$ & - & $1.1302 \pm 0.1164$ & 1.1449 & 1.1630 & 1.56 \\
\hline
\end{tabular}

for supporting this 1 yprk under the Universiti Putra Malaysia GRANT No. GIPM/2015/9464700 and GP-

\section{CONCLUSION}

In conclusion, we have demonstrated photothermal imaging using non-contact pyroelectric method. Thermal image of thin film sample of $\mathrm{Al}, \mathrm{Cu}, \mathrm{Ni}$ as well as $\mathrm{Cu}$ with artificial defect were obtained by raster scanning the sample using $\mathrm{He}-\mathrm{Ne}$ laser $(532 \mathrm{~nm})$ at frequency modulation of $6 \mathrm{~Hz}$ and lock-in detection in the range of 50 to $500 \mathrm{mV}$ depending of studied material. Furthermore, we also evaluated thermal diffusivity of $\mathrm{Al}, \mathrm{Cu}$ and $\mathrm{Ni}$ film effectively. By using normalization technique, the amount of media parameters has been removed effectively, where the value of the thermal diffusivity of thin film $\mathrm{Al}, \mathrm{Cu}$ and $\mathrm{Ni}$ were well in line with the values of literature.

\section{ACKNOWLEDGEMENTS}

The authors are grateful to Universiti Putra Malaysia
IPS/2018/9664200.

\section{REFERENCES}

Almond, D.P. \& Patel, P.M. 1996. Photothermal Science and Technique. London: Chapman \& Hall.

Azmi, B.Z., Liaw, H.S., Yunus, W.M.M., Hashim, M., Moksin, M.M. \& Yusoff, W.M.D.W. 2004. Normalisation procedure in thermal wave approach of thermal diffusivity measurement of solids using pyroelectric sensor. Infrared Phys. \& Technol. 45: 315-321.

Bennett, C.A. \& Patty, R.R. 1982. Thermal wave interferometry: A potential application of the photoacoustic effect. Appl. Optics 21: 49-54.

Delenclos, S., Chirtoc, M., Sahraoui, A.H., Kolinsky, C. \& Buisine, J.M. 2001. A new calibration procedure for the determination of thermal parameters and their temperature dependence using the photopyroelectric method. Analytical Sciences 17: s161-s164.

Lide, R.D. 1997. Handbook of Chemisty and Physics. 78thedition. Boca Raton: CRC Press Inc.

Mandelis, A. 2011. Perspective: Photopyroelectric effects and pyroelectric measurements: Photopyroelectric calorimeter 
for the simultaneous thermal, optical, and structural characterization of samples over phase transitions. Review of Scientific Instruments 82(12901): 1-3.

Murphy, J.C. \& Aamodt, L.C. 1980. Photothermal spectroscopy using optical beam probing: Mirage effect. J. Appl. Phys. 51: 4580.

Parker, W.J., Jenkins, R.J., Butler, C.P. \& Abbot, G.L. 1961. Flash method of determining thermal diffusivity, heat capacity, and thermal conductivity. J. Appl. Phys. 32: 1979.

Sang, L.H. 2003. Photopyroelectric technique in thermal diffusivity determination and spectroscopic response of solid. Master Thesis, University Putra Malaysia (Unpublished).

Taylor, R.E. \& Maglic, K.D. 1984. In Compendium of Thermophysical Property Measurement Methods, edited by Maglic, K.D., Cezairliyan, A. \& Peletsky, V.E. 1st edition. New York: Plenum.
Wong, P., Fung, P. \& Tam, H. 1998. Low thermal diffusivity measurements of thin films using mirage technique. J. Appl. Phys. 84: 6623.

Zakaria, A., Sang, L.H., Abbas, Z., Yunus, W.M.M. \& Hassan, J. 2006. Measurement of thermal parameter using noncontact photopyroelectric method. ScienceAsia 32(1): 47-52.

Photoacoustic Laboratory

Department of Physics

Faculty of Science

Universiti Putra Malaysia

43400 Serdang, Selangor Darul Ehsan

Malaysia

*Corresponding author; email: kamilah@upm.edu.my

Received: 24 September 2019 